\title{
PENGARUH PEMBERIAN ASI EKSKLUSIF TERHADAP KEMBALINYA MENSTRUASI PADA IBU MENYUSUI DI RS ST. CAROLUS JAKARTA
}

\author{
Popy Irawati ${ }^{1}$, Mohammad Hakimi ${ }^{2}$, Ova Emilia ${ }^{3}$
}

\begin{abstract}
Background: Exclusive breastfeeding has benefit for both the baby and mother. The breastfeeding patterns have a close relation with return of menses. Breastfeeding practice in Indonesia is rare (27-40\%) and $37,4 \%$ babies received a weaned food, and only $10 \%$ babies received six months exclusive breastfeeding. In Jakarta, most mothers realized benefit of breastfeeding for their babies and family themselves. This research is located at St. Carolus Hospital because St. Carolus is a centre of lactation in Jakarta

Objective: To identify the impact of exclusive breastfeeding on median time of return of menses on breastfeeding mother in St. Carolus hospital.

Method: An observational study with retrospective cohort study design. Samples are a year breastfeeding's mother in St. Carolus Hospital. The total samples are 129 respondents. The samples are available with consecutive sampling. The data were analyzed using univariable, bivariable and multivariable methods. Bivariable statistic tests were chi square, log rank and Kaplan Meier's survival analyzed methods. The multivariable statistic test was cox regression Hazard model.

Result and Discussion: Median time of the return of menses on exclusive breastfeeding group was 20 weeks, and an unexclusive breastfeeding is 12 weeks. The breastfeeding pattern and the return of menses on breastfeeding mother are significant related $(\mathrm{HR}=2,4 ; \mathrm{Cl} 95 \%=1,65-3,55 ; \mathrm{P}<0,05)$. The return menses an exclusive breastfeeding mother was 2,4 times longer than unexclusive breastfeeding mother at a certain survival point. The variables of ages, parity, education, occupation, family economic status and health status are not significantly associated with the return of menses.

Conclusion: There is a significant different median time of the return of menses between exclusive and unexclusive breastfeeding mothers.
\end{abstract}

Keywords: exclusive breastfeeding, the return of menses, breastfeeding.

\begin{abstract}
ABSTRAK
Latar Belakang: Menyusui secara eksklusif memiliki manfaat baik untuk ibu maupun bayinya. Pola menyusui berhubungan erat dengan kembalinya menstruasi. Praktek menyusui di Indonesia relatif jarang (27-40\%) dan sebanyak $37,4 \%$ bayi menerima makanan tambahan, serta hanya $10 \%$ saja yang mendapatkan ASI eksklusif selama 6 bulan. Di Jakarta, sebagian besar ibu sebenarnya menyadari manfaat menyusui untuk bayi dan keluarganya. Penelitian ini mengambil lokasi di RS St. Carolus karena St. Carolus merupakan pusat laktasi di Jakarta.

Tujuan: Mengidentifikasi pengaruh menyusui eksklusif dengan nilai median kembalinya menstruasi pada ibu menyusui di RS St. Carolus.

Metode: Penelitian ini adalah penelitian observasional dengan disain kohort retrospektif. Subyek penelitian adalah ibu menyusui di RS St. Carolus dalam periode 1 tahun. Jumlah total subyek sebanyak 129 responden. Subyek penelitian diambil dengan metode consecutive sampling. Data dianalisis secara univariat, bivariat dan multivariat. Analisis statistik untuk data bivariat menggunakan chi square, log rank dan Kaplan Meier. Analisis multivariat menggunakan metode cox regression hazard.
\end{abstract}

\footnotetext{
Badan Koordinator Keluarga Berencana Nasional Pusat

2,3 Bagian Obstetri dan Ginekologi, Fakultas Kedokteran, Universitas Gadjah Mada
} 
Hasil dan Pembahasan: Nilai median untuk kembalinya menstruasi pada ibu yang menyusui eksklusif adalah 20 minggu sedangkan pada ibu yang menyusui tidak eksklusif adalah 12 minggu. Pola menyusui dan kembalinya menstruasi berhubungan secara bermakna ( $H R=2,4 ; C l 95 \%=1,65-3,55 ; P<0,05)$. Risiko untuk kembali menstruasi pada ibu yang menyusui eksklusif sebesar 2,4 kali lebih lama dibandingkan ibu yang tidak menyusui eksklusif. Variabel usia, paritas, pendidikan, pekerjaan, status sosial ekonomi dan status kesehatan tidak berhubungan secara bermakna dengan kembalinya menstruasi.

Kata Kunci: pemberian ASI eksklusif, kembalinya menstruasi, pemberian ASI

\section{PENDAHULUAN}

Menstruasi merupakan peristiwa keluarnya darah dari vagina karena luruhnya dinding rahim yang banyak mengandung pembuluh darah (endometrium). Hari pertama dari menstruasi disebut sebagai hari pertama dari siklus menstruasi. Menstruasi terjadi secara rutin setiap bulan. ${ }^{1}$

Menurut WHO, menyusui adalah pemberian air susu ibu (ASI) dari baik secara langsung maupun diperas ${ }^{3}$. Pemberian ASI adalah metode ideal dalam memberikan makanan kepada bayi. ASI merupakan bentuk makanan terlengkap bagi bayi, ASI melindungi bayi dari bermacam-macam penyakit infeksi dan non infeksi, dan menyusui memperbaiki kesehatan ibu dengan mengurangi perdarahan postpartum dan menurunkan risiko kanker payudara. ${ }^{4}$

Pemberian ASI menunda kembalinya menstruasi setelah melahirkan dan amenore karena menyusui berhubungan dengan tertekannya ovulasi. I Ibu yang memberikan ASI, lebih sedikit mendapatkan perdarahan pasca persalinan, lebih cepat terjadi involusi rahim dan penundaan kembalinya ovulasi dengan peningkatan jarak anak. ${ }^{6}$

Selama 20 tahun terakhir banyak penelitian menunjukkan bahwa telah terjadi penurunan pemberian ASI pada daerah perkotaan di negara berkembang. ${ }^{7}$ Selain itu penelitian yang dilakukan di negara maju memperlihatkan, bahwa lamanya amenore karena menyusui lebih pendek pada wanita yang mengenalkan makanan tambahan selain ASI lebih awal. ${ }^{8}$
Berdasarkan data SDKI 2002-2003 secara keseluruhan median lama pemberian ASI hanya 22,3 bulan, median lama pemberian ASI eksklusif 1,6 bulan dan median lama pemberian ASI utama (ASI saja, ASI dan air putih, cairan lain atau jus) adalah 2,0 bulan. Data di Propinsi DKI Jakarta menunjukkan pemberian ASI masih sangat rendah dibandingkan secara nasional, yakni terlihat dari median lama pemberian ASI hanya 14,4 bulan, median lama pemberian ASI eksklusif 0,6 bulan dan median lama pemberian ASI utama adalah 1,5 bulan. Sedangkan persentase anak yang pernah disusui adalah $94,2 \%{ }^{9}$

Lamanya waktu pemberian ASI juga dapat menekan fertilitas ibu, karena hisapan bayi merangsang pengeluaran (sekresi) hormon dalam tubuh ibu yang menunda kembalinya ovulasi, sehingga menunda kehamilan karena menurunkan fertilitas secara tidak langsung. Penelitian ini bertujuan untuk mengetahui pengaruh pemberian ASI eksklusif terhadap kembalinya menstruasi pada ibu menyusui di RS St Carolus Jakarta.

\section{METODE}

Penelitian ini adalah observasional dengan menggunakan pendekatan kuantitatif dan rancangan retrospective cohort, yaitu subjek diamati dalam kurun waktu tertentu terhadap suatu faktor resiko kemudian dipelajari efek yang terjadi. ${ }^{10}$ Data yang digunakan berasal dari rekam medik Rumah Sakit ST Carolus Jakarta. Pada rancangan ini peneliti meneliti perbedaan median waktu antara pola pemberian ASI (variabel bebas) dengan kembalinya menstruasi pada 
ibu menyusui (variabel tergantung), dengan melihat karakteristik responden seperti umur, jumlah anak hidup, pendidikan, status ekonomi, status pekerjaan dan status kesehatan (variabel luar).

Lokasi penelitian ini di Rumah Sakit St. Carolus di Jakarta. Populasi dalam penelitian ini adalah semua ibu menyusui yang memenuhi syarat untuk wawancara individu yang tercatat di rekam medik pada Rumah Sakit St. Carolus Jakarta selama tahun 2008. Subjek adalah ibu yang menyusui minimal 6 bulan. Kriteria eksklusi adalah ibu yang sedang memberikan ASI tetapi sedang memakai alat kontrasepsi.

Besar sampel menggunakan rumus perhitungan besar sampel survival analysis menurut proportional hazard model. ${ }^{11}$ Maka total sampel yang didapat adalah 129.

Analisis data yang digunakan adalah untuk melihat pola pemberian ASI dengan karakteristik responden. Analisis data bivariat untuk melihat hubungan antara variabel bebas terhadap variabel terikat serta hubungan antara variabel luar terhadap variabel terikat dengan menggunakan uji statistik chi square, log rank dan survival analisis Kaplan Meier. Analisis data multivariat menggunakan coxproportional hazard model untuk mengetahui perbandingan dari masing-masing variabel terhadap kembalinya menstruasi pada ibu yang menyusui.

\section{HASIL DAN PEMBAHASAN}

Penelitian dilakukan sejak tanggal 5 September -1 November 2008. Jumlah sampel dan responden sebanyak 129 dengan hasil penelitian sebagai berikut:

\section{Deskripsi Responden}

Karakteristik kembalinya menstruasi pada ibu menyusui diperoleh melalui analisis univariabel seperti pada Tabel 1.
Tabel 1. Karakteristik responden

\begin{tabular}{|c|c|c|}
\hline Variabel & $\mathbf{n}$ & $\%$ \\
\hline \multicolumn{3}{|l|}{ Pola pemberian ASI: } \\
\hline eksklusif & 74 & 57,36 \\
\hline tidak eksklusif & 55 & 42,64 \\
\hline \multicolumn{3}{|l|}{ Umur } \\
\hline $20-35$ & 114 & 88,37 \\
\hline$<20 \&>35$ & 15 & 11,63 \\
\hline \multicolumn{3}{|l|}{ Pendidikan } \\
\hline SMA & 31 & 24,03 \\
\hline DII/DIII & 34 & 26,36 \\
\hline $\mathrm{S} 1 / \mathrm{s} 2$ & 64 & 49,61 \\
\hline \multicolumn{3}{|l|}{ Jumlah anak } \\
\hline Paritas 1-2 & 26 & 20,16 \\
\hline Paritas $>3$ & & \\
\hline \multicolumn{3}{|c|}{ Status Ekonomi Keluarga } \\
\hline \multicolumn{3}{|c|}{ Cukup (>850000) } \\
\hline \multirow[t]{2}{*}{ Kurang $(\leq 850000)$} & 53 & 41,09 \\
\hline & 76 & 68,91 \\
\hline \multicolumn{3}{|l|}{ Pekerjaan Ibu } \\
\hline Tidak & 42 & 32,56 \\
\hline $\mathrm{Ya}$ & 87 & 67,44 \\
\hline \multicolumn{3}{|c|}{$\begin{array}{l}\text { Status Kesehatan Ibu } \\
\text { (sakit sehingga tidak bisa } \\
\text { memberi ASI) }\end{array}$} \\
\hline Tidak & 120 & 93,02 \\
\hline Ya & 9 & 6,98 \\
\hline
\end{tabular}

Dari tabel diatas menunjukkan bahwa pola pemberian ASI secara eksklusif sebesar 74 orang (57,36\%) dan yang tidak eksklusif adalah 55 orang (42,64\%). Umur ibu antara 20-35 tahun sebanyak 114 orang $(88,37 \%)$, lebih banyak dari ibu yang berumur kurang dari 20 tahun dan lebih dari 35 tahun yaitu sebanyak 15 orang (11,63\%). Pendidikan responden yang terbanyak adalah sarjana S1 sebesar 64 orang $(49,61 \%)$, disusul DII/DIII sebanyak 34 orang $(26,36 \%)$ dan yang paling sedikit adalah SMA sebanyak 31 orang $(24,03 \%)$. Responden yang memiliki anak antara 1-2 orang sebesar 103 orang $(79,84 \%)$ lebih banyak dibandingkan responden yang meiliki anak lebih dari 3 orang yaitu 26 orang $(20,16 \%)$. Status sosial ekonomi keluarga responden 
yang cukup sebanyak 76 orang $(68,91 \%)$ dan yang kurang sebanyak 53 orang (41,09\%). Responden yang bekerja lebih banyak sebesar 87 orang $(67,44 \%)$ dibandingkan dengan yang tidak bekerja sebanyak 42 orang (32,56\%). Status kesehatan responden sehingga tidak bisa memberi ASI sebanyak 9 orang $(6,98 \%)$ dan yang sehat sebanyak 120 orang $(93,02 \%)$.
1. Hubungan antara Variabel Bebas, Variabel Pengganggu, dan Variabel Luar terhadap Variabel Terikat.

Analisis ini menggunakan log rank untuk mengetahui perbedaan kembalinya menstruasi terhadap pemberian $\mathrm{ASI}$, umur, paritas, pendidikan, status ekonomi keluarga, pekerjaan ibu dan status kesehatan ibu terhadap kembalinya menstruasi pada ibu menyusui. Hasil analisis dapat dilihat pada tabel di bawah ini:

Tabel 2. Hasil analisis log rank kembalinya menstruasi terhadap pemberian ASI, umur, pendidikan, jumlah anak, status ekonomi keluarga, pekerjaan ibu dan status kesehatan ibu.

\begin{tabular}{|c|c|c|c|c|}
\hline VARIABEL & $\begin{array}{l}\text { Observasi } \\
\text { kejadian }\end{array}$ & $\begin{array}{c}\text { Ekspektasi } \\
\text { kejadian }\end{array}$ & $x^{2}$ & $\mathrm{p}$ \\
\hline \multicolumn{5}{|l|}{ Pemberian ASI: } \\
\hline eksklusif & 74 & 95,69 & 25,84 & $0,001^{*}$ \\
\hline tidak eksklusif & 54 & 32,31 & 1 & \\
\hline \multicolumn{5}{|l|}{ Umur } \\
\hline $20-35$ & 113 & 112,26 & 0,05 & 0,81 \\
\hline$<20 \&>35$ & 15 & 15,74 & 1 & \\
\hline \multicolumn{5}{|l|}{ Pendidikan } \\
\hline SMA & 32 & 24,17 & 4,32 & 0,12 \\
\hline DII/DIII & 34 & 34,57 & & \\
\hline $\mathrm{S} 1 / \mathrm{S} 2$ & 62 & 69,26 & 1 & \\
\hline \multicolumn{5}{|l|}{ Jumlah anak } \\
\hline Paritas 1-2 & 102 & 103,03 & 0,07 & 0,79 \\
\hline Paritas $>3$ & 26 & 24,97 & 1 & \\
\hline \multicolumn{5}{|l|}{ Status Ekonomi } \\
\hline \multicolumn{5}{|l|}{ Keluarga } \\
\hline Cukup (>850000) & 52 & 60,03 & 2,72 & 0,09 \\
\hline Kurang ( $\leq 850000)$ & 76 & 67,97 & 1 & \\
\hline \multicolumn{5}{|l|}{ Pekerjaan Ibu } \\
\hline Tidak & 41 & 41,19 & 0,00 & 0,96 \\
\hline Ya & 87 & 86,81 & 1 & \\
\hline \multicolumn{5}{|l|}{ Status Kesehatan } \\
\hline \multicolumn{5}{|l|}{$\begin{array}{l}\text { Ibu } \\
\text { (sakit sehingga tidak } \\
\text { bisa memberi ASI) }\end{array}$} \\
\hline Tidak & 119 & 122,13 & 2,11 & 0,14 \\
\hline Ya & 9 & 5,87 & 1 & \\
\hline
\end{tabular}

Keterangan: $\mathrm{X}^{2}=$ chi square $p=p$ value 
Pada tabel diatas terlihat ada perbedaan waktu kembalinya menstruasi pada setiap item variabel. Hasil penelitian menujukkan bahwa median waktu kembalinya menstruasi pada pemberian ASI secara eksklusif adalah 20 minggu dan tidak eksklusif adalah 12 minggu. Hasil analisis menunjukkan bahwa kembalinya menstruasi mempunyai hubungan yang signifikan dengan pola pemberian ASI $(p=0,001)$. Pada variabel umur responden menunjukkan median waktu yang berbeda, yaitu pada umur antara 20-35 tahun median waktunya lebih lama yaitu 16 minggu dibandingkan dengan yang berumur lebih dari 35 tahun yaitu 12 minggu. Variabel pendidikan responden menunjukkan bahwa median waktu lama kembalinya menstruasi pada yang berpendidikan DII/ DIII paling lama yaitu 20 minggu, sedangkan yang berpendidikan sarjana S1 adalah 16 minggu dan yang SMA adalah 12 minggu. Pada variabel paritas, responden yang mempuyai anak lebih dari 3 mempunyai median waktu kembalinya menstruasi lebih lama yaitu 20 minggu dibandingkan dengan responden yang mempunyai anak 1-3 orang adalah 16 minggu. Variabel status ekonomi keluarga menunjukkan bahwa responden yang mempunyai status ekonomi kurang mempunyai median waktu kembalinya menstruasi selama 17 minggu sedangkan status ekonomi yang cukup adalah 16 minggu. Pada variabel pekerjaan ibu menunjukkan bahwa median waktu lama kembalinya menstruasi baik pada ibu yang bekerja maupun pada ibu yang tidak bekerja adalah sama yaitu 16 minggu. Dan pada variabel status kesehatan ibu terlihat median waktu kembalinya menstruasi pada ibu yang tidak sakit lebih lama yaitu 16 minggu dibandingkan dengan ibu yang pernah sakit sehingga tidak bisa memberikan ASI yaitu 12 minggu.

\section{Hubungan antara Variabel Luar terhadap Variabel Bebas}

Pada analisis bivariabel ini untuk melihat apakah ada hubungan antara variabel luar (umur, pendidikan, paritas, pekerjaan ibu, status ekonomi keluarga dan status kesehatan ibu) dengan variabel bebas (pemberian ASI eksklusif). Hasil yang didapatkan melalui penghitungan secara statistik, yaitu:

Tabel 3. Hubungan antara pemberian ASI dengan umur, pendidikan, paritas, status ekonomi keluarga, pekerjaan ibu, dan status kesehatan ibu

\begin{tabular}{|c|c|c|c|c|c|}
\hline \multirow{2}{*}{ Variabel } & \multicolumn{2}{|c|}{ Pemberian ASI } & \multirow{2}{*}{$x^{2}$} & \multirow{2}{*}{$\mathrm{RR}$} & \multirow{2}{*}{$\mathrm{p}$} \\
\hline & Eksklusif & Tidak eksklusif & & & \\
\hline \multicolumn{6}{|l|}{ Umur } \\
\hline $20-35$ & $64(56,4)$ & $50(43,86)$ & 0,6 & 0,76 & 0,43 \\
\hline$<20 \&>35$ & $10(66,67)$ & $5(33,33)$ & & 1 & \\
\hline \multicolumn{6}{|l|}{ Pendidikan } \\
\hline SMA & $19(59,38)$ & $13(40,63)$ & 0,082 & 1,06 & 0,97 \\
\hline DII/DIII & $19(55,88)$ & $15(44,12)$ & & & \\
\hline S1/S2 & $36(57,14)$ & $27(42,86)$ & & 1 & \\
\hline \multicolumn{6}{|l|}{ Jumlah anak } \\
\hline Paritas 1-2 & $56(54,37)$ & $47(45,63)$ & 1,87 & 0,67 & 0,17 \\
\hline Paritas $>3$ & $18(69,23)$ & $8(30,77)$ & & 1 & \\
\hline \multicolumn{6}{|l|}{$\begin{array}{l}\text { Status Ekono mi } \\
\text { Keluarga }\end{array}$} \\
\hline Cukup $(>850000)$ & $27(50,94)$ & $26(49,06)$ & 1,51 & 0,77 & 0,21 \\
\hline Kurang ( $\leq 850000$ ) & $47(61,84)$ & $29(38,16)$ & & 1 & \\
\hline \multicolumn{6}{|l|}{ Pekerjaan ibu } \\
\hline Tidak & $34(80,95)$ & $8(19,05)$ & 14,16 & 2,83 & $0,001 *$ \\
\hline $\mathrm{Ya}$ & $10(15,98)$ & $17(51,02)$ & & 1 & \\
\hline \multicolumn{6}{|l|}{$\begin{array}{l}\text { Status Kesehatan } \\
\text { Ibu }\end{array}$} \\
\hline Tidak & $69(57,50)$ & $51(12,50)$ & 0,012 & 1,05 & 0,090 \\
\hline Ya & $5(55,56)$ & $4(44,44)$ & & 1 & \\
\hline
\end{tabular}

Keterangan: $X^{2}=$ chi square $\quad R R=$ Risk Ratio $p=p$ value 
Hasil analisis dari tabel 3 , setelah dihitung secara statistik ditemukan bahwa hasil analisa variabel pekerjaan ibu adalah ( $\mathrm{RR}=2,83 ; 95 \% \mathrm{Cl}=1,47-5,44)$, artinya adalah ibu yang tidak bekerja memberikan ASI secara eksklusif 2,83 kali lebih sering dibandingkan dengan ibu yang bekerja.

Analisis multivariabel dilakukan untuk mengetahui kekuatan pengaruh pola pemberian ASI terhadap kembalinya menstruasi pada ibu menyusui setelah disesuaikan dengan variabel lain. Uji statistik pada analisis multivariabel ini menggunakan Cox Proportional Hazard model. Adapun yang bermakna secara praktis pada bivariabel adalah variabel umur, paritas dan status kesehatan ibu. Pola pengukuran ditampilkan dalam 5 model.

Tabel 4. Hasilanalisis cox proportional hazard model untuk mengetahui pengaruh kembalinya menstruasi pada ibu menyusui berdasarkan pemberian asi, umur, paritas, status kesehatan ibu dan pekerjaan ibu

\begin{tabular}{|c|c|c|c|c|c|}
\hline Variabel & $\begin{array}{l}\text { Model I } \\
\text { HR } \\
\text { (Cl 95\%) }\end{array}$ & $\begin{array}{l}\text { Model II } \\
\text { HR } \\
\text { (Cl 95\%) }\end{array}$ & $\begin{array}{l}\text { Model III } \\
\text { HR } \\
\text { (Cl 95\%) }\end{array}$ & $\begin{array}{l}\text { Model IV } \\
\text { HR } \\
\text { (CI 95\%) }\end{array}$ & $\begin{array}{l}\text { Model V } \\
\text { HR } \\
\text { (Cl 95\%) }\end{array}$ \\
\hline \multicolumn{6}{|l|}{ Pemberian ASI: } \\
\hline eksklusif & $2,4^{*}$ & $2,5^{*}$ & $2,4^{*}$ & $2,7^{*}$ & $2,7^{*}$ \\
\hline \multirow[t]{2}{*}{ tidak eksklusif } & $(1,65-3,55)$ & $(1,66-3,66)$ & $(1,66-3,58)$ & $(1,79-4,08)$ & $(1,80-4,11)$ \\
\hline & 1 & 1 & 1 & 1 & 1 \\
\hline \multicolumn{6}{|l|}{ Umur } \\
\hline $20-35$ & & 1,1 & & & 1,1 \\
\hline \multirow[t]{2}{*}{$<20 \&>35$} & & $(0,64-1,9)$ & & & $(0,58-1,99)$ \\
\hline & & 1 & & & 1 \\
\hline \multicolumn{6}{|l|}{ Paritas } \\
\hline $1-2$ & & & 1,1 & & 1,1 \\
\hline \multirow[t]{2}{*}{$>3$} & & & $(0,72-1,71)$ & & $(0,68-1,81)$ \\
\hline & & & 1 & & 1 \\
\hline \multicolumn{6}{|l|}{ Status Kesehatan } \\
\hline Ibu & & & & 1,64 & 1,68 \\
\hline Tidak & & & & $(0,83-3,28)$ & $(0,84-3,35)$ \\
\hline Ya & & & & 1 & 1 \\
\hline Pekerjaan ibu & & & & 0,73 & 0,74 \\
\hline Tidak & & & & $(0,49-1,11)$ & $(0,49-1,12)$ \\
\hline Ya & & & & 1 & 1 \\
\hline $\begin{array}{l}\text { Deviance (-2. Log } \\
\text { likelihood) }\end{array}$ & 1001,82 & 1003,7 & 1003,6 & 1000 & 998 \\
\hline$X$ perbedaan (df) & & $-1,88(1)$ & $0,1(1)$ & $1,82(2)$ & $2,00(4)$ \\
\hline$P$ value & & 0,17 & 0,75 & 0,22 & 0,94 \\
\hline Log rank & 19,86 & 19,98 & 20,07 & 23,67 & 23,91 \\
\hline $\mathrm{N}$ & 129 & 129 & 129 & 129 & 129 \\
\hline
\end{tabular}

Keterangan:

* = signifikan

$\mathrm{df}=$ derajat bebas

$\mathrm{HR}=$ Hazard Ratio

$P=P$ value

$\mathrm{Cl}=$ Cumulative incidence

$\mathrm{N}=$ jumlah sampel 


\section{a). Analisis Model 1}

Berdasarkan hasil analisis multivariat pada model I diatas menunjukkan bahwa pengaruh pemberian ASl eksklusif dengan kembalinya menstruasi pada ibu menyusui, sehingga ditemukan hasil hitungan secara statistik bahwa (HR=2,4; Cl 95\%=1,65-3,55; $p<0,05)$ Artinya secara statistik hubungan antara kembalinya menstruasi pada ibu menyusui baik dengan pemberian ASI eksklusif terbukti bermakna. Resiko belum kembalinya menstruasi pada ibu menyusui pada pemberian ASI secara eksklusif 2,4 kali lebih lama dibandingkan dengan ibu yang menyusui secara tidak eksklusif, dengan kesintasan pada titik tertentu. Rentang interval keyakinan menunjukkan bahwa kita percaya $\mathrm{HR}=2,4$ terletak antara rentang 1,65-3,55 pada populasi terjangkau.

\section{b) Analisis Model II}

Dari hasil analisis multivariat pada model II diatas menunjukkan bahwa pengaruh variabel pemberian ASI terhadap kembalinya menstruasi pada ibu menyusui dengan memasukkan variabel umur ibu, sehingga ditemukan hasil hitungan secara statistik bahwa (HR=2,5; $\mathrm{Cl} 95 \%=1,66-3,66 ; p<0,05)$. Artinya secara statistik hubungan antara kembalinya menstruasi pada ibu menyusui dengan pemberian ASI setelah dimasukkan variabel umur ibu terbukti bermakna. Resiko ibu yang memberikan ASI secara eksklusif dan umur ibu 20-35 mempunyai waktu belum kembalinya menstruasi 2,5 kali lebih lama dibandingkan dengan ibu yang menyusui secara tidak eksklusif, dengan kesintasannya pada titik tertentu. Rentang interval keyakinan menunjukkan bahwa kita percaya $\mathrm{HR}=2,5$ terletak antara rentang 1,66-3,66 pada populasi terjangkau.

\section{c) Analisis Model III}

Dari hasil analisis multivariat pada model III diatas menunjukkan bahwa pengaruh pemberian ASI eksklusif terhadap kembalinya menstruasi pada ibu menyusui dengan memasukkan variabel paritas, sehingga ditemukan hasil penelitian secara statistik dengan ( $H R=2,4 ; C l 95 \%=1,66-3,58 ; p<0,05)$. Artinya secara statistik hubungan antara kembalinya menstruasi pada ibu menyusui dengan pemberian ASI setelah dimasukkan variabel paritas terbukti bermakna. Resiko ibu yang memberikan ASI secara eksklusif dengan paritas 1-2 mempunyai waktu belum kembalinya menstruasi 2,4 kali lebih lama dibandingkan dengan ibuyang menyusui secara tidak eksklusif, dengan kesintasan pada titik tertentu. Rentang interval keyakinan menunjukkan bahwa kita percaya $\mathrm{HR}=2,4$ terletak antara rentang $1,66-3,58$ pada populasi terjangkau.

\section{d) Analisis Model IV}

Dari hasil analisis multivariat pada model IV diatas menunjukkan bahwa pengaruh pemberian ASI eksklusif terhadap kembalinya menstruasi pada ibu menyusui dengan memasukkan variabel status kesehatan ibu, sehingga ditemukan hasil penelitian secara statistik dengan ( $\mathrm{HR}=2,4 ; \mathrm{Cl} 95 \%=1,66-3,58$; $p<0,05)$ Artinya secara statistik hubungan antara kembalinya menstruasi pada ibu menyusui dengan pemberian ASI eksklusif setelah dimasukkan variabel status kesehatan terbukti bermakna. Resiko ibu yang memberikan ASI secara eksklusif dengan tidak adanya penyakit mempunyai waktu belum kembalinya menstruasi 2,4 kali lebih lama dibandingkan dengan ibu yang menyusui secara tidak eksklusif, dengan kesintasan pada titik tertentu. Rentang interval keyakinan menunjukkan bahwa kita percaya $\mathrm{HR}=2,4$ terletak antara rentang 1,66-3,58 pada populasi terjangkau.

\section{e) Analisis Model V}

Dari hasil analisis multivariat pada model $\mathrm{V}$ diatas menunjukkan bahwa pengaruh pemberian ASI eksklusif terhadap kembalinya menstruasi pada ibu menyusui dengan memasukkan variabel umur, paritas dan status kesehatan ibu sehingga ditemukan hasil hitungan secara statistik bahwa $(\mathrm{HR}=2,5 ; \mathrm{Cl}$ $95 \%=1,68-3,65 ; p<0,05)$ Artinya secara statistik hubungan antara kembalinya menstruasi pada ibu menyusui dengan pemberian ASI eksklusif setelah dimasukkan variabel umur, paritas dan status kesehatan ibu terbukti bermakna. Resiko ibu yang memberikan ASI secara eksklusif dengan umur ibu 20-35, paritas 1-2 dan tidak adanya penyakit mempunyai waktu belum kembalinya menstruasi 2,5 kali lebih lama dibandingkan dengan ibu yang 
menyusui secara tidak eksklusif, dengan kesintasan pada titik tertentu. Rentang interval keyakinan menunjukkan bahwa kita percaya $\mathrm{HR}=2,5$ terletak antara rentang 1,68-3,65 pada populasi terjangkau.

Dari hasil analisis penelitian yang telah dilakukan maka dirumuskan pembahasan sebagai berikut:

\section{Waktu Kembalinya Menstruasi pada Ibu Menyusui Berdasarkan Pemberian ASI}

Median waktu kembalinya menstruasi pada pemberian ASI secara eksklusif terjadi pada minggu ke-20 dan yang tidak eksklusif terjadi pada minggu ke-12. Kembalinya menstruasi pada pemberian ASI secara eksklusif pada 75\% adalah 16 minggu sedangkan yang tidak eksklusif 8 minggu. Pada hasil uji statistik bivariat menunjukkan hubungan yang signifikan antara pemberian ASI secara eksklusif dengan kembalinya menstruasi. Hasil tersebut sesuai dengan penelitian yang dilakukan daerah kota dan desa di Babol Iran dengan median waktu 5 bulan (20 minggu). ${ }^{13}$

Pada analisis multivariat hazard ratio, pemberian ASI dengan kembalinya menstruasi pada ibu menyusui menunjukkan perbedaan yang signifikan dengan hazard ratio adalah sebesar 2,4. Hal tersebut juga sesuai dengan teori yang menyebutkan bahwa waktu menyusui panjang dapat memperlama waktu risiko tidak terjadi konsepsi dan dapat menjarangkan kelahiran karena menurunkan fertilitas secara tidak langsung. ${ }^{13}$ Penelitian di banyak negara secara konsisten menunjukkan bahwa menyusui berhubungan dengan tertundanya siklus menstruasi dan ovulasi, mengurangi fekunditas dan jarak kelahiran yang lebih panjang. ${ }^{14}$ Secara ilmiah dapat dibuktikan bahwa pemberian ASI akan menekan ovulasi yang ditunjukan dengan serial postpartum basal dan pengukuran suhu badan. ${ }^{16}$

2. Waktu Kembalinya Menstruasi pada Ibu Menyusui Berdasarkan Variabel Luar (Umur Ibu, Pendidikan Ibu, Paritas, Pekerjaan Ibu, Status Ekonomi Keluarga, dan Kesehatan Ibu)

a. Waktu Kembalinya Menstruasi pada Ibu Menyusui Berdasarkan Umur Ibu.

Umur ibu antara 20-35 tahun sebanyak
114 orang $(88,37 \%)$. Median waktu kembalinya menstruasi pada ibu umur 2035 tahun lebih lama terjadi yaitu pada minggu ke-16, sedangkan pada ibu umur lebih dari 35 tahun terjadi pada minggu ke-12.

Pada analisis bivariat menunjukkan tidak ada hubungan yang tidak signifikan antara umur ibu dengan waktu kembalinya menstruasi. Hasil ini tidak sesuai dengan penelitian Manan et al. yang menunjukkan pemberian ASI pada ibu 20-34 mempunyai hubungan yang signifikan dengan waktu kembalinya menstruasi. ${ }^{13}$

b. Waktu Kembalinya Menstruasi pada Ibu Menyusui Berdasarkan Pendidikan Ibu

Pendidikan responden yang terbanyak adalah sarjana S1 sebesar 64 orang $(49,61 \%)$. Median waktu kembalinya menstruasi pada ibu berpendidikan DII/ DIII paling lama terjadi yaitu pada minggu ke-20, pada ibu berpendidikan Sarjana S1/S2 terjadi di minggu ke-16 dan paling cepat terjadi pada ibu berpendidikan SMA yaitu di minggu ke-12.

Hasil analisis bivariat menunjukkan bahwa tidak ada hubungan yang signifikan antara pendidikan ibu dengan kembalinya menstruasi. Hal tersebut berbeda dengan penelitian Ojofeitimi yang menunjukkan kembalinya menstruasi lebih cepat secara signifikan pada ibu berpendidikan tinggi dibanding-kan ibu dengan pendidikan terbatas. ${ }^{17}$

c. Waktu Kembalinya Menstruasi pada Ibu Menyusui Berdasarkan Paritas.

Hasil penelitian menunjukan responden yang memiliki anak antara 1-2 orang sebesar 103 orang (79,84\%). Median waktu kembalinya menstruasi pada ibu yang mempunyai anak lebih dari 3 orang lebih lama terjadi yaitu pada minggu ke20 dan pada ibu dengan jumlah anak 1-2 orang terjadi di minggu ke-16. 
Pada analisis bivariat hasil statistik menunjukkan bahwa hubungan tidak signifikan. Hasil ini tidak sesuai dengan penelitian Hajian-Tilaki yang dilakukan di daerah kota dan desa di Babol Iran yang menunjukkan pada paritas 1-2 mempunyai hubungan yang signifikan. ${ }^{18}$

Hasil uji statistik pada analisis multivariat menunjukkan bahwa hubungan yang tidak signifikan antara pendidikan ibu dengan kembalinya menstruasi. Hasil ini tidak sesuai dengan penelitian Manan et alyang menunjukkan bahwa ada hubungan yang signifikan baik secara statistik maupun praktis antara paritas dengan kembalinya menstruasi. ${ }^{13}$

d. Waktu Kembalinya Menstruasi pada Ibu Menyusui Berdasarkan Pekerjaan Ibu.

Responden yang tidak bekerja sebanyak 42 orang $(32,56 \%)$, dan yang tidak bekerja sebanyak (33,1\%). Median waktu kembalinya menstruasi pada ibu bekerja maupun dengan ibu yang tidak bekerja adalah sama yaitu terjadi pada minggu ke16.

Pada analisis bivariat hasil statistik menunjukkan bahwa hubungan yang tidak signifikan antara status pekerjaan ibu dengan kembalinya menstruasi. Hasil ini tidak sesuai dengan penelitian Gross dan Burger yang menyatakan bahwa pemberian ASI menunda kembalinya menstruasi dan ovulasi tetapi lamanya amenore karena menyusui bervariasi pada setiap populasi dan beberapa faktor lain diantaranya adalah pekerjaan ibu ${ }^{5}$.

e. Waktu Kembalinya Menstruasi pada Ibu Menyusui Berdasarkan Status Ekonomi Keluarga

Pada analisis univariat status sosial ekonomi keluarga responden yang cukup sebanyak 76 orang (68,91\%). Median waktu kembalinya menstruasi pada ibu dengan status sosial ekonomi kurang terjadi lebih lama yaitu pada minggu ke17 dan pada ibu dengan status sosial ekonomi terjadi di minggu ke-16.

Pada analisis bivariat menunjukkan hubungan yang tidak signifikan antara status sosial ekonomi dengan kembalinya menstruasi. Hasil ini tidak sesuai dengan penelitian McNeilly yang menyatakan bahwa ada beberapa faktor seperti faktor sosio ekonomi yang berhubungan baik dengan ibu maupun dengan anaknya terkait dengan pengaruh dari lamanya amenore karena menyusui. ${ }^{19}$

f. Waktu Kembalinya Menstruasi pada Ibu Menyusui Berdasarkan Status Kesehatan Ibu.

Pada analisis univariat responden sehingga tidak bisa memberi ASI sebanyak 9 orang $(6,98 \%)$ dan yang sehat sebanyak 120 orang (93,02\%). Median waktu kembalinya menstruasi pada ibu yang tidak pernah sakit selama menyusui terjadi lebih lama yaitu pada minggu ke16 dibanding dengan ibu yang pernah sakit selama menyusui yaitu terjadi di minggu ke-12.

Pada analisis bivariat menunjukkan hubungan yang tidak signifikan antara status kesehatan dengan kembalinya menstruasi. Hasil tersebut tidak sejalan dengan penelitian Wei dan Yi yang menyatakan bahwa banyak faktor yang mempengaruhi kelanjutan dari mentruasi dan ovulasi pada wanita postpartum diantaranya adalah status kesehatan ibu. ${ }^{20}$

Hasil analisis multivariat menunjukkan hubungan yang tidak signifikan antara pendidikan ibu dengan kembalinya menstruasi. Hal ini tidak sesuai dengan penelitian Manan et al yang mengatakan bahwa ibu sehat mempunyai hubungan yang signifikan dengan waktu kembalinya menstruasi. ${ }^{13}$ 


\section{KESIMPULAN DAN SARAN}

Median waktu kembalinya menstruasi pada ibu menyusui pada pemberian ASI secara eksklusif lebih lama dibandingkan dengan pemberian ASI yang tidak eksklusif. Ibu menyusui secara eksklusif mempunyai resiko belum kembalinya menstruasi lebih lama dibandingkan dengan ibu yang menyusui secara tidak eksklusif pada titik kesintasan tertentu. Variabel umur, paritas, dan status kesehatan ibu, secara praktis bermakna, namun secara statistik tidak bermakna, hal tersebut dari nilai $p$ Value $>0,05$. Variabel pendidikan ibu, status ekonomi keluarga dan pekerjaan ibu secara statistik dan praktis tidak bermakna.

Perlunya pemantauan dan melaksanakan program ASI eksklusif 6 bulan pada unit-unit pelayanan KIA bagi provider dan stakeholder. Perlunya penekanan kepada ibu postpartum supaya segera memberikan ASI eksklusif kepada bayinya selama 6 bulan untuk meningkatkan kesehatan dan pertumbuhan bayi. Pemberian konseling tentang ASI harus dimulai sejak ibu hamil agar ibu dapat mempersiapkan fisik dan mental saat menyusui nanti.

\section{DAFTAR PUSTAKA}

1. Obstetrics and Gynecology. Women health (Information for Young Women): menstruation. 1999; Access http://www.womenhealth. net/ html/youngwomen/ menstruation.html. date 1 june 2008.

2. A.D.A.M. Inc. Menstruation, women's health center. 2002; Access http://www.healthandage.com/ html/well-connected/pdf/doc.101.pdf. Date 24 Mei 2008.

3. World Health Organization (WHO). Global strategy for instant and young child feeding, Geneva. 2003.

4. Roesli U. Mengenal ASI eksklusif, ed. 4. Trubus Agriwidaya. Jakarta. 2007.

5. Gross BA, Burger $\mathrm{H}$. Breastfeeding patterns and return to fertility in australian women. Aust NZJ Obstet Gynaecol. 2002; 42(2)148.

6. King J. Contraception and lactation. J Midwifery Womens Health. 2007; (52) 14-620.
7. Prema K, Naidu AN, Kumari SN. Lactation and fertility. The American Journal of Clinical Nutrition. 1979; 32.1298-1303.

8. Prema K, Ravindranath $M$. The effect of breastfeeding supplements on the return of fertility. Studies in family planning. 1982; 13(10)293-296.

9. Badan Pusat Statistik (BPS) dan ORC Macro. Survey demografi dan kesehatan indonesia 2002-2003, Calverton, Maryland, USA: ORC Macro. 2003.

10. Gordis L. Epidemiology, $3^{\text {rd }}$ ed. Elsevier Inc. USA. 2004.

11. Rosner B. Fundamental of biostatistics, $6^{\text {th }}$ ed. Thomson Brooks Publisher. 2006.

12. Egbuonu I, Ezechukwu CC, Chukwuka JO, Ikechebelu JI. Breastfeeding, return of menses, sexual activity and contraceptive practice among mothers in the first six month of lactation in onitsha, South Eastern Nigeria. Journal of Obstetric and Gynecology. 2005; 25(5)500-503.

13. Manan HR, Islam MN. Breast-feeding in bangladesh: patterns and impact on fertility. Journal of Biosocial Science. 1996; 18(4) 425-434.

14. Aguirre GP, Jones RE. Breastfeeding and postpartum amenorrhea in rural guatemala, Centro Centroamericano de Poblacio. 2005; 3 (1) 4.

15. Simondon KB, Delaunay V, Diallo A, Elguero, Simondon F. Lactational amenorrhea is associated with child age at the time of introduction of complientary food: a prospective cohort study in rural senegal, West Africa. Am J Clin Nutr. 2003; 78. 154-61.

16. Cronin, T.J. () Influence of lactation upon ovulation. The Lancet. 1968; 2(7565): $422-424$

17. Ojofeitimi, E.O. Effect of duration and frequency of breastfeeding on postpartum amenorrhea. Pediatrics. 1982; 69.164-168

18. Hajian-Tilaki, K.O. Factors affecting the pattern of postpartum amenorrhea. Annals of Saudi Medicine. 2002; (22)5-6.

19. McNeilly AS. Breastfeeding and the suppression of fertility. Human Reproduction. 1996; (11) 950-955.

20. Wei L, Yi Q. Relation of supplementary feeding to resumptions of menstruation and ovulation in lactating postpartum women. Chin Med J. 2007; 120(10): 868-870. 